\title{
RESPONSE OF TWO SOYBEAN CULTIVARS TO DIFFERENT LEVELS ORGANIC FERTILIZER (COMPOST) Abd El-Hafez, G.A. ${ }^{1}$ and A. A. Abo El-Soud ${ }^{2}$ \\ 1-Field Crops Institute, Agric. Res. Center (ARC), Giza, Egypt. 2-Microbiology Dept., Soils, Water \& Environ. Res. Institute (SWERI), ARC. Giza; Egypt.
}

\begin{abstract}
Two field experiments were conducted to study the response of two soybean cultivars to different levels of organic fertilizer (compost) on nodulation, nitrogen fixation, growth, yield and yield characters during two successive summer seasons of 2005 and 2006 at the experimental farm of Mallawi Agriculture Research Station, Minia Governerate, Egypt. The soybean cultivars used were Giza 111 and Crawford. Treatments were five different levels of compost, zero, 500, 1000, 1500 and $2000 \mathrm{~kg}$ compost/fed compared with the Bradyrhizobium inoculated soybean plus starter dose of nitrogen fertilizer $(20 \mathrm{~kg} \mathrm{~N} / \mathrm{fed}$ ) or uninoculated soybean fertilized with the recommended dose of nitrogen fertilizer ( $70 \mathrm{~kg} \mathrm{~N} / \mathrm{fed}$ ). A split plot layout with four replications was used.

Results showed that the inoculation with Bradyrhizobium in combination with compost gave significant increases in nodule number and dry weight as well as dry weight of shoots and nitrogen content compared with the inoculated plants without compost in Giza 111 and Crawford cultivars.

Also, results showed the superiority of Giza 111 cultivar for increasing nodulation, growth, yield and its components (nodule number and dry weight, shoot dry weight, seed and straw yields/fed, plant height, branches number and pods number per plant, seed weight/plant and 100- seed weight,).

As well as results revealed that all different levels of compost increased significantly growth, seed yield and its components as compared with the control. The highest increase was recorded with $2000 \mathrm{~kg}$ rate of compost /fed. followed by 1500 $\mathrm{kg} / \mathrm{fed}$. The highest values of plant height, branch number, pods number, seed yield/plant, 100-seed weight, seed and straw yields were obtained from the interaction between Giza 111x 2000 kg compost/fed.

It can be stated that applying different compost levels to soybean plants was the recommended for raising soybean productivity and reducing the environmental pollution under condition of the present study.
\end{abstract}

\section{INTRODUCTION}

Soybean [Glycine max (L.) Merrill] is one of the most important annual pulse crops in the world. The cultivated form is used in human food and livestock feeds (Harry and Kwon, 1987). Soybean seeds are one of the main sources of protein and oil in plants. The seed contains approximately $40 \%$ protein and $21 \%$ edible oil, which used in making margarine. It has been called "yellow jewel", "nature's miracle protein" and "meat of the field" (Noureldin, 1998). The oil is used essentially in margarine, salad oils, cooking oil and shortening. Moreover soybean products became more important because of low costs, nutritionally balanced and beverages for human consumption.

Thus it is important to increase production by increasing the cultivated area or rising per unit area yield by applying the most suitable cultural practices such as compost and growing various new cultivates.

In Egypt, the use of organic materials as fertilizers began to decline, while the use of mineral fertilizers is increasing. At the moment, crop residues are utilized largely for burning, industry and animal feed. The amounts of farmyard 
manure available to the Egyptian farmer are not sufficient and it is very poor in organic matter and plant nutrient contents. Hence, the disintegration of the organic fertilizers in soil is very important in order to achieve the important roles of its activity. The available of amount farmyard manure to the Egyptian farm ofare not only insufficient but also decreasing with the increasing tendency towards the mechanization of agriculture. An alternative way to meet the growing needs for organic manure is by composting plant and animal residues (Abd-El Ghaffar, 1978). Compost is an eco-friendly fertilizer, it is positively improves soil structure, aggregate formation, drought protection, stopping erosion, buffering, reduces fertilizer requirements and gives nutrients when plants need them as well as inoculates the soil with vast numbers of beneficial microbes. Thus, compost can modify soil physical properties and strongly affects its chemical and biological ones (Abdel-Malek et al., 1961; Martin and Gershuny, 1992; Mekail, 1998 and. Fontaine et al., 2003).

Many investigators reported that using compost with several crops including legume crops almost duplicated the observed yields besides controlling numerous of soil born diseases (Hoitink et al., 1993). Eghball (2002) reported that after four years of nitrogen or phosphorus based manure and compost applications, soil surface carbon and nitrogen concentration and quantities were greater in the nitrogen compared with the phosphorus based management systems.

Soybean cultivars exhibited differences in its plant height, number of branches, seeds and pods/plant, seed index, seed and straw yields/fed. (Negra and Chirita,. 1994 and Abd El-Hafez, 1999).

The aim of this work was to study the effect of different levels of organic compost on the nodulation, growth, yield and yield components for two soybean cultivars plants. Moreover, to minimize the environmental pollution, resulted from the intensive use of chemical fertilization by substituting a part of it with organic fertilizer (compost).

\section{MATERIALS AND METHODS}

Two field experiments were conducted during two successive summer seasons of 2005 and 2006 at Mallawi Agric. Res. Station Farm, Minia Governorate, Egypt to study the effect of different levels of organic fertilizer (compost) on nodulation, growth, yield and it's components for two soybean cultivars.

\section{Soil Sampling:}

Representative soil samples were collected from the top $30 \mathrm{~cm}$ layer of the Experimental fields, sieved through $2 \mathrm{~mm}$ screen and air-dried. The main physical and chemical properties of the soil in both tested seasons were analyzed according to Page et al. (1982) and recorded in Table (1).

\section{Microbial strains:}

All microorganisms used in preparing bio-organic fertilizer (compost) such as cellulose decomposers, (Trichoderma ressie), phosphate dissolving bacteria (Bacillus megatherium var phosphaticum) and nitrogen fixing bacteria (Azotobacter chroococcum) were prepared in Biofertilizers Production Unit; Microbiology Department; SWERI, ARC, Giza, Egypt. Also, mixtures of two strains of Bradyrhizobium japonicum USDA 110 and HH303 (approximately $10^{\circ}$ cells $/ \mathrm{ml}$ ) used in soybean inoculation were prepared and added to sterile solid carrier (vermiculite $+10 \%$ peat) to prepare the inoculant used for soybean inoculation. 
Table (1): Some physical and chemical properties of the surface layer $(0.0-30 \mathrm{~cm})$ of the studied soil at two seasons of 2005 and 2006

\begin{tabular}{|c|c|c|}
\hline Physical and chemical properties & First season 2005 & Second season 2006 \\
\hline \multicolumn{3}{|c|}{ Particles size distribution } \\
\hline Sand \% & 20.70 & 19.95 \\
\hline Silt \% & 34.05 & 35.00 \\
\hline Clay \% & 45.25 & 45.05 \\
\hline Texture grade & Clayey & Clayey \\
\hline $\mathrm{pH}(1: 5$ soil water suspension) & 8.00 & 7.92 \\
\hline E.C. $\left(\mathrm{dS} / \mathrm{m}\right.$ at $\left.25^{\circ} \mathrm{C}\right)$ & 1.75 & 1.61 \\
\hline Organic matter \% & 0.94 & 0.96 \\
\hline \multicolumn{3}{|c|}{ Soluble cations (meq/L) } \\
\hline $\mathrm{Ca}^{++}$ & 4.27 & 4.14 \\
\hline $\mathrm{Mg}^{++}$ & 2.34 & 2.41 \\
\hline $\mathrm{Na}^{+}$ & 7.49 & 7.46 \\
\hline $\mathrm{K}^{+}$ & 2.72 & 2.65 \\
\hline \multicolumn{3}{|c|}{ Soluble anions (meg/L) } \\
\hline $\mathrm{CO}_{3}^{-}$ & 0.00 & 0.00 \\
\hline $\mathrm{HCO}_{3}^{-}$ & 1.86 & 1.91 \\
\hline $\mathrm{Cl}^{-}$ & 2.39 & 2.41 \\
\hline $\mathrm{SO}_{4}^{--}$ & 12.57 & 12.34 \\
\hline
\end{tabular}

\section{Preparation of compost:}

Compost was a mixture of farm residues (corn and cotton stalks, sesame and soybean straw) inoculated with special bio-decomposer strains of bacteria, fungi under aerobic condition. First, enriched compost was prepared using raw materials of farm residues shredded into $1.5 \mathrm{~cm}$. Farmyard manure collected from Mallawi, Agric. Res. Station farm, Minia Governorate, Egypt were used. Moreover, some microbial inoculants such as cellulose decomposers, phosphate dissolving bacteria and nitrogen fixing bacteria were added to the mixture.

To set up the heap, the remain raw materials were mixed with farmyard manure and inoculated with microbial then built in successive layers tamped well over the bed mixture of raw materials up to $1 \mathrm{~m}$ high. Moisture was maintained to $60 \%$ and the moistening was considered satisfactory when a hand full of composted materials would wet the hand but not drip. This heap was turned up down every 15 days for 75 days (till maturation). Samples were taken at maturation of heap construction, mixed thoroughly, air dried and ground to chemical, physical and microbiological determinations (Table 2).

\section{Plant cultivars:}

Soybean seeds Giza 111 and Crawford were kindly provided by Field Crops Research Institute, ARC, Giza, Egypt.

\section{Field experiments:}

Two consequence field experiments were done at the experimental farm of Mallawi Agriculture Research station. Minia, Governerate, Egypt.

The compost was added before cultivation during soil preparation. A split plot design was used in this study with four replicates. The tested cultivars were set up randomly in the main plots while the compost treatments were arranged at random in subplots of $3 \times 3.5 \mathrm{~m}$ with $60 \mathrm{~cm}$ apart between ridges (5 ridges/subplot). Compost was added at the rates of zero, 500, 1000, 1500 and $2000 \mathrm{~kg} / \mathrm{fed}$ at 15 days before cultivation during soil preparation. Superphosphate $\left(15.5 \% \mathrm{P}_{2} \mathrm{O}_{5}\right)$ and potassium sulfate $\left(48 \% \mathrm{~K}_{2} \mathrm{O}\right)$ were incorporated into soil before sowing at the rates of 200 and $50 \mathrm{~kg} / \mathrm{fed}$, respectively. 
Table (2): Characteristics the bio-compost used in the field experiment

\begin{tabular}{|l|c|}
\hline Properties & Values \\
\hline $\mathrm{pH}$ & 7.28 \\
E.C. $\left(\mathrm{dS} / \mathrm{m}\right.$ at $\left.25^{\circ} \mathrm{C}\right)$ & 4.18 \\
Organic matter $(\%)$ & 36.07 \\
Organic-C (\%) & 24.97 \\
Total N (\%) & 1.20 \\
C/N ratio & 20.8 \\
Total-P (\%) & 1.04 \\
Total-K (\%) & 0.52 \\
Total soluble-N (ppm) & 642.5 \\
Available-P ( ppm) & 276.0 \\
Available-K (ppm) & 725.4 \\
Total count of bacteria & $26 \times 10^{7}$ \\
Total count of fungi & $16 \times 10^{6}$ \\
Total count of actinomycetes & $10 \times 10^{6}$ \\
\hline
\end{tabular}

Sowing soybean seeds took place on May 4 th and 10 th during summer seasons of 2005 and 2006, respectively. Soybean seeds were cultivated as recommended practice and inoculated with effective strains of Bradyrhizobium japonicum using Arabic gum solution as adhesive material just before sowing. Inoculant was applied at rate of $600 \mathrm{~g}$ per $60 \mathrm{~kg}$ soybean seeds. Soybean seedlings were thinned out to two plants/hill at 21 days from sowing. The other recommended agronomic practices for soybean cultivation were used just before sowing. The control treatments were inoculated with soybean plus starter dose of nitrogen fertilizer ( $20 \mathrm{~kg} \mathrm{~N} / \mathrm{fed}$ ) and uninoculated fertilized with the recommended dose of nitrogen fertilizer (70 kg N/fed).

\section{The following treatments were studied:}

Bradyrhizobium inoc. $+0 \mathrm{Kg}$ compost/fed

Bradyrhizobium inoc. $+500 \mathrm{Kg}$ compost/fed

Bradyrhizobium inoc. $+1000 \mathrm{Kg}$ compost/fed

Bradyrhizobium inoc. $+1500 \mathrm{Kg}$ compost/fed

Bradyrhizobium inoc. $+2000 \mathrm{Kg}$ compost/fed

Bradyrhizobium inoc. $+20 \mathrm{Kg} \mathrm{N} / \mathrm{fed}$

Un-inoc. $+70 \mathrm{KgN} / \mathrm{fed}$

Five plants samples were randomly taken from each plot at 60 days after planting to determine nodule number and dry weight as well as shoot dry weight and its nitrogen contents according to Page et al. (1982)...

At harvest, ten guarded plants were randomly chosen to determine plant height $(\mathrm{cm})$ number of branches and pods/ plant, seed weight (g)/plant and weight of 100-seed (seed index). Also, seed and straw yield (ton/fed) were estimated from the three central ridges of each subplot. Seed and straw nitrogen content were determined according to Page et al. (1982).

\section{Statistical analysis:}

The analysis of variances was made separately for each season, and then a combined analysis of seasons, cultivars and treatments was made according to Gomez and Gomez (1984).

\section{1-Effect of the interaction:}

\section{RESULTS AND DISCUSSION}

Results of two soybean cultivars after 60 days of plant grown under two successive seasons as affected by Bradyrhizobium inoculation combined with 
different levels of organic fertilizer (compost) are given in Table (3). Obtained data showed that all nodulation and vegetative growth parameters were significantly affected by different treatments under study. The uninoculated plants received the recommended dose of $70 \mathrm{~kg} \mathrm{~N} / \mathrm{fed}$ did not produce nodules number or dry weight in the two cultivars at both seasons, indicating that the specific indigenous Bradyrhizobium japonicum in the experimental soils are absent.

Table (3): Effect of Bradyrhizobium inoculation combined with different levels of compost on nodulation and growth of two soybean cultivars during the two seasons of 2005 and 2006

\begin{tabular}{|c|c|c|c|c|c|c|c|c|}
\hline \multirow{3}{*}{ Treatments } & \multicolumn{4}{|c|}{ Nodulation } & \multicolumn{4}{|c|}{ Shoot } \\
\hline & \multicolumn{2}{|c|}{ Number / plant } & \multicolumn{2}{|c|}{$\begin{array}{l}\text { Dry weight } \\
\text { (mg/plant) }\end{array}$} & \multicolumn{2}{|c|}{$\begin{array}{c}\text { Dry weight } \\
\text { (g/plant) }\end{array}$} & \multicolumn{2}{|c|}{$\begin{array}{l}\text { N-content } \\
\text { (mg/plant) }\end{array}$} \\
\hline & $\begin{array}{l}\text { Giza } \\
111\end{array}$ & Crawford & $\begin{array}{c}\text { Giza } \\
111\end{array}$ & Crawford & $\begin{array}{c}\text { Giza } \\
111\end{array}$ & Crawford & $\begin{array}{c}\text { Giza } \\
111\end{array}$ & Crawford \\
\hline \multicolumn{9}{|c|}{ Season 2005} \\
\hline $\begin{array}{lll}\text { Inoc. } \quad+\quad 0 & \mathrm{Kg} \\
\text { compost/fed } & \end{array}$ & 8 & 6 & 86.2 & 72.3 & 28.5 & 21.6 & 584.3 & 399.6 \\
\hline $\begin{array}{l}\text { Inoc. }+500 \quad \mathrm{Kg} \\
\text { compost/fed }\end{array}$ & 15 & 10 & 163.5 & 98.4 & 35.4 & 32.6 & 764.6 & 625.9 \\
\hline $\begin{array}{l}\text { Inoc. }+1000 \quad \mathrm{Kg} \\
\text { compost/fed }\end{array}$ & 19 & 12 & 243.6 & 102.6 & 38.6 & 35.7 & 907.1 & 731.9 \\
\hline $\begin{array}{l}\text { Inoc. }+1500 \mathrm{Kg} \\
\text { compost/fed }\end{array}$ & 20 & 15 & 257.4 & 115.4 & 48.5 & 42.8 & 1290.1 & 1005.8 \\
\hline $\begin{array}{l}\text { Inoc. }+2000 \mathrm{Kg} \\
\text { compost/fed }\end{array}$ & 22 & 16 & 268.4 & 187.6 & 56.2 & 46.8 & 1539.9 & 1132.6 \\
\hline $\begin{array}{l}\text { Inoc. }+20 \mathrm{Kg} \\
\text { N/fed }\end{array}$ & 20 & 18 & 254.8 & 151.6 & 51.2 & 44.6 & 1318.6 & 1052.6 \\
\hline $\begin{array}{l}\text { Un-inoc. } \\
\text { 70KgN/fed }\end{array}$ & 0 & 0 & 0 & 0 & 54.7 & 49.2 & 1559.0 & 1254.6 \\
\hline LSD 0.05 & & 2.1 & & 0.6 & & .3 & & 36.4 \\
\hline \multicolumn{9}{|c|}{ Season 2006} \\
\hline \begin{tabular}{lll|} 
Inoc. $\quad+\quad 0$ & $\mathrm{Kg}$ \\
compost/fed & \\
\end{tabular} & 10 & 8 & 92.5 & 84.6 & 30.4 & 27.6 & 656.64 & 524.4 \\
\hline $\begin{array}{l}\text { Inoc. }+500 \mathrm{Kg} \\
\text { compost/fed }\end{array}$ & 18 & 13 & 186.3 & 105.6 & 36.5 & 33.5 & 448.95 & 643.2 \\
\hline $\begin{array}{l}\text { Inoc. }+1000 \mathrm{Kg} \\
\text { compost/fed }\end{array}$ & 22 & 16 & 266.5 & 113.5 & 46.8 & 36.8 & 1132.56 & 721.28 \\
\hline $\begin{array}{l}\text { Inoc. }+1500 \mathrm{Kg} \\
\text { compost/fed }\end{array}$ & 25 & 18 & 2648 & 135.9 & 50.2 & 44.3 & 1345.36 & 877.14 \\
\hline $\begin{array}{l}\text { Inoc. }+2000 \mathrm{Kg} \\
\text { compost/fed }\end{array}$ & 27 & 20 & 292.6 & 165.7 & 53.4 & 48.5 & 1452.48 & 1028.2 \\
\hline $\begin{array}{l}\text { Inoc. }+20 \mathrm{Kg} \\
\mathrm{N} / \mathrm{fed}\end{array}$ & 26 & 18 & 284.7 & 157.6 & 52.6 & 45.8 & 1378.12 & 893.1 \\
\hline $\begin{array}{l}\text { Un-inoc.+70Kg } \\
\text { N/fed }\end{array}$ & 0 & 0 & 0 & 0 & 55.8 & 49.6 & 1551.24 & 1066.4 \\
\hline LSD 0.05 & & 2.6 & & 4.6 & & .2 & & 8.6 \\
\hline
\end{tabular}

Inoculation with Bradyrhizobium japonicum plus starter dose of nitrogen caused significant increases over the inoculated without nitrogen fertilizer control in number \& dry weight of nodules by 150.0 \& $195.6 \%$ for Giza 111 cultivar and by 200.0 \& $109.7 \%$ for Crawford cultivar in the first season, respectively. The corresponding increases in the second season were $160.0 \& 207.8 \%$ and $200.0 \&$ $86.3 \%$, respectively.

Moreover, Bradyrhizobium inoculation combined with compost $(2000 \mathrm{~kg}$ compost/fed) caused significant increases in nodule number and dry weight compared to Bradyrhizobium inoculation alone. These increases at the first and second seasons were 175.0 and $170.0 \%$ in Giza 111 cultivar, respectively. The corresponding increases in Crawford cultivar were 166.7 and $150.0 \%$ in the seam order during two seasons. The increases in nodules dry weight due to these treatments over the inoculation without compost in Giza 111 variety were 211.4, $216.3 \%$ during the first and second seasons, respectively. While, these increases were 159.5 and $95.9 \%$ for Crawford variety at first and second seasons, respectively. 
Data presented in Table (3) revealed that inoculated treatment without compost recorded the lowest dry weight of Giza 111 shoots (28.5 and 30.4 $\mathrm{g} /$ plant) and the lowest nitrogen content (584.4 and $656.6 \mathrm{mg} \mathrm{N} / \mathrm{plant}$ ) at the first and second season, respectively.

Similar trends were obtained in inoculated Crawford cultivar without compost, where shoots dry weight recorded $21.6 \& 27.6 \mathrm{~g} / \mathrm{plant}$ and nitrogen content of $399.6 \& 524.4 \mathrm{mg} \mathrm{N} /$ plant during the two seasons in the same order.

In Giza 111 cultivar, the uninoculated plants received the full dose of nitrogen (70 kg N/fed) increased shoot dry weight \& nitrogen content by 91.9 \& $166.8 \%$ and $83.6 \& 136.2 \%$ over the control at the first and second season, respectively. While, in Crawford cultivar these increases were $127.8 \& 214.0 \%$ and $79.7 \& 103.4 \%$ in the same order during the two seasons.

Inoculation with Bradyrhizobium in combination with compost gave significant increases in dry weight of shoots and nitrogen content compared with the inoculated plants without compost in Giza 111 and Crawford cultivars.

Bradyrhizobium in combination with compost (2000 kg compost/fed) increased shoots dry weight \& N-content of Giza 111 plant by 97.2 \& $163.5 \%$ over the Bradyrhizobium alone, respectively at the first season. These increases were 75.7 and $121.2 \%$ at the second season. While, in Crawford cultivar the increases in dry weight of shoots \& N-content were 116.4 \& $183.4 \%$ in the same order at the first season. In the second season, these increases were $75.7 \&$ $96.1 \%$, respectively.

These increases could be due to the biological role of Rhizobium in enhancing plant growth and $\mathrm{N}_{2}$-fixation as reported by Abo El-Soud et al. (2004) and Mekhemar et al. (2005).

Data again revealed that the maximum dry weight of shoots and nitrogen content were obtained in plants inoculated with Bradyrhizobium combined with $2000 \mathrm{~kg}$ compost/fed followed by those inoculated with Bradyrhizobium combined with starter dose of nitrogen fertilizer.

The interaction between two soybean cultivars and different levels of compost on the plant high, branch number, pods number per plant and 100-seed weight in 2005 and 2006 seasons are presented in Table (4). The highest values (118.0 cm, 3.3 branches, 7.9 pods and $20.9 \mathrm{~g}$, respectively) were obtained by sowing Giza111 cultivar with 2000 kg compost/fed followed by, sowing Giza111 with $1500 \mathrm{~kg}$ compost /fed, while sowing Crawford with zero (control) recorded the lowest in all previous mentioned characters.

Regarding seed and straw yields of Giza111 and Crawford cultivars, results in Table (5) exhibited significant differences in seed and straw yields between plants inoculated with Bradyrhizobium alone or combined with different compost levels and uninoculated plants, which received $70 \mathrm{~kg} \mathrm{~N} / \mathrm{fed}$. The inoculation of plants without compost application recorded the lowest values of seed and straw yields in the first and second seasons. The highest seed yield was achieved with $2000 \mathrm{~kg}$ compost/fed during both tested seasons. Then yield tended to decrease due to the use of $1500 \mathrm{~kg}$ compost/fed. The significant differences in seed and straw yields were recorded as compost levels from zero to $500,1000.1500$ and $2000 \mathrm{~kg} / \mathrm{fed}$ and soybean cultivars. Soybean, Giza 111 inoculated with Bradyrhizobium combined with 500, 1000, 1500 and $2000 \mathrm{~kg}$ compost/fed increased seed yield by $32.1,74.5,130.5$ and $196.3 \%$ and straw yield by $38.0,72.4,159.8$ and $166.6 \%$ over the inoculated plants without compost in the first season, respectively. While, in the second season which recorded 
increases of $30.1,66.6,117.0$ and $123.6 \%$ in seed yield at the same order for plants inoculated with Bradyrhizobium combined with 500, 1000, 1500 and 2000 $\mathrm{kg}$ compost/fed. The increases in straw yield were 11.6, 40.0, 75.9 and $82.0 \%$, respectively.

Similar trends were observed in Crawford cultivar, when inoculated with Bradyrhizobium combined with 500, 1000, 1500 and $2000 \mathrm{~kg}$ compost/fed, since the seed yield increased by $25.6,61.0,84.4$ and $109.5 \%$ and straw yield by 11.7 , 45.8, 60.5 and $96.7 \%$ over the inoculated plants without compost in the first season, respectively. While, in the second season, which recorded increases of $14.8,23.3,59.5$ and $63.2 \%$ in seed yield at the same order for plants inoculated with Bradyrhizobium combine with 500, 1000, 1500 and $2000 \mathrm{~kg}$ compost/fed. The increases in straw yield were 11.6, 40.0, 75.9 and $82.0 \%$, respectively.

The increase in seed and straw yields of soybean cultivars may be due to that compost has direct impacts on plant growth, yield and its attributes; these direct impacts come from providing the plants by the important nutrients for growth and metabolism. Adjacent to the direct impacts, there are two indirect ones, the first is out of compost hydrolysis in soil, and humic acid is produced, which played an important role in reducing soil $\mathrm{pH}$ and increasing soil nutrient availability to the plants. Beside the role of humic acid as a rich fertilizer itself, the second indirect impact is the preferable consequence of compost on the soil mechanical properties to improve soil physical properties including water-holding capacity and reduces the probability of soil borne infection (Hoitink et al., 1993).

Table (4): Effect of Bradyrhizobium inoculation combined with different levels of compost on yield component of two soybean cultivars during the two seasons of 2005 and 2006

\begin{tabular}{|c|c|c|c|c|c|c|c|c|}
\hline \multirow{2}{*}{ Treatments } & \multicolumn{2}{|c|}{ Plant height (cm) } & \multicolumn{2}{|c|}{$\begin{array}{c}\text { Branches number } \\
\text { /plant }\end{array}$} & \multicolumn{2}{|c|}{$\begin{array}{c}\text { Pods number } \\
\text { / plant }\end{array}$} & \multicolumn{2}{|c|}{$\begin{array}{c}\text { 100-Seed weight } \\
\text { (g) }\end{array}$} \\
\hline & $\begin{array}{l}\text { Giza } \\
111\end{array}$ & Crawford & $\begin{array}{l}\text { Giza } \\
111\end{array}$ & Crawford & $\begin{array}{l}\text { Giza } \\
111\end{array}$ & Crawford & $\begin{array}{c}\text { Giza } \\
111\end{array}$ & Crawford \\
\hline \multicolumn{9}{|c|}{ Season 2005} \\
\hline $\begin{array}{lrr}\text { Inoc. } & + & 0 \\
\text { compost/fed }\end{array}$ & 62.7 & 58.3 & 1.3 & 1.2 & 36.0 & 30.3 & 11.5 & 10.4 \\
\hline $\begin{array}{l}\text { Inoc. }+500 \\
\text { compost/fed }\end{array}$ & 75.8 & 63.7 & 1.7 & 1.5 & 45.3 & 35.3 & 13.4 & 11.3 \\
\hline $\begin{array}{l}\text { Inoc.+1000 Kg } \\
\text { compost/fed }\end{array}$ & 88.0 & 74.6 & 2.6 & 2.5 & 53.1 & 40.7 & 14.9 & 12.3 \\
\hline $\begin{array}{l}\text { Inoc. }+1500 \mathrm{Kg} \\
\text { compost/fed }\end{array}$ & 109.4 & 81.1 & 3.2 & 2.8 & 63.2 & 49.3 & 19.7 & 15.1 \\
\hline $\begin{array}{l}\text { Inoc. }+2000 \mathrm{Kg} \\
\text { compost/fed }\end{array}$ & 118.0 & 84.2 & 3.3 & 2.8 & 71.9 & 44.7 & 20.9 & 15.3 \\
\hline $\begin{array}{l}\text { Inoc. }+20 \mathrm{Kg} \\
\mathrm{N} / \mathrm{fed}\end{array}$ & 112.6 & 79.2 & 2.8 & 2.8 & 58.8 & 45.2 & 18.7 & 14.8 \\
\hline $\begin{array}{l}\text { Un-inoc.+ } \\
70 K g N / \text { fed }\end{array}$ & 114.5 & 89.6 & 3.4 & 3.1 & 69.8 & 46.8 & 20.8 & 16.7 \\
\hline LSD 0.05 & & 7.1 & & .3 & & 5.0 & & 2.1 \\
\hline \multicolumn{9}{|c|}{ Season 2006} \\
\hline $\begin{array}{lrl}\text { Inoc. }+ & + & 0 \\
\text { compost/fed }\end{array}$ & 62.4 & 53.3 & 1.3 & 1.0 & 41.3 & 33.3 & 12.8 & 11.5 \\
\hline $\begin{array}{l}\text { Inoc. + } 500 \mathrm{Kg} \\
\text { compost/fed }\end{array}$ & 73.8 & 60.3 & 1.9 & 1.3 & 47.7 & 36.7 & 14.4 & 12.7 \\
\hline $\begin{array}{l}\text { Inoc. }+1000 \mathrm{Kg} \\
\text { compost/fed }\end{array}$ & 83.0 & 70.3 & 2.9 & 1.9 & 56.4 & 42.7 & 16.1 & 13.6 \\
\hline $\begin{array}{l}\text { Inoc. }+1500 \mathrm{Kg} \\
\text { compost/fed }\end{array}$ & 100.7 & 75.2 & 3.4 & 2.2 & 70.9 & 52.3 & 20.2 & 16.1 \\
\hline $\begin{array}{l}\text { Inoc. }+2000 \mathrm{Kg} \\
\text { compost/fed }\end{array}$ & 108.0 & 76.3 & 3.8 & 2.8 & 78.3 & 46.3 & 22.6 & 15.7 \\
\hline $\begin{array}{l}\text { Inoc. }+20 \mathrm{Kg} \\
\text { N/fed }\end{array}$ & 98.5 & 74.6 & 3.2 & 2.4 & 68.9 & 45.2 & 18.6 & 15.2 \\
\hline $\begin{array}{l}\text { Un-inoc.+70Kg } \\
\mathrm{N} / \text { fed }\end{array}$ & 104.0 & 78.4 & 3.5 & 3.0 & 74.5 & 50.6 & 22.5 & 16.8 \\
\hline LSD 0.05 & & 6.4 & & .7 & & .1 & & 4.0 \\
\hline
\end{tabular}


From the abovementioned results, it can be stated that the application of $2000 \mathrm{~kg}$ compost/fed before sowing soybean could be recommended for raising soybean productivity and decreasing pollution through decreasing mineral nitrogen application under the environmental condition of the present study.

Table (5): Effect of Bradyrhizobium inoculation combined with different levels of compost on seed and straw yield of two soybean cultivars during the two seasons of 2005 and 2006

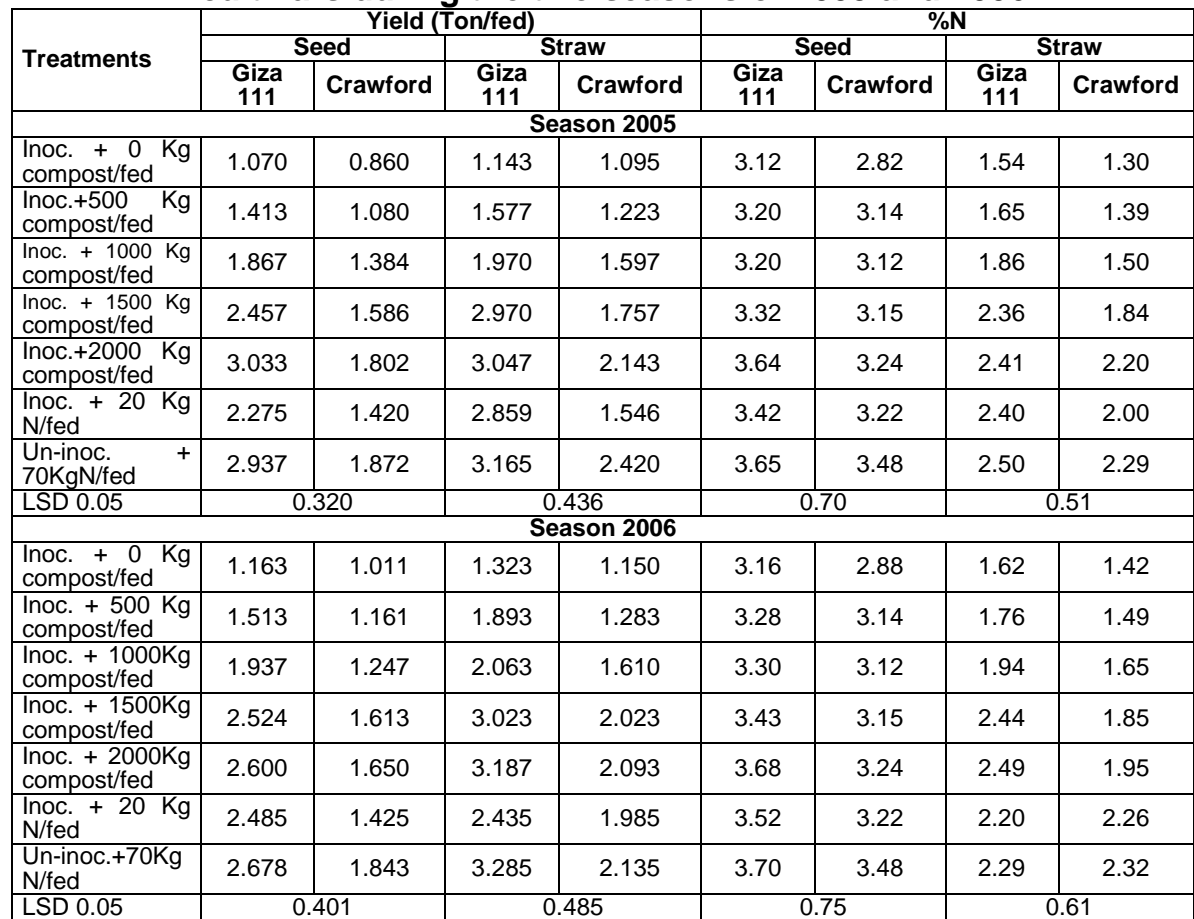

\section{2- Statistical main effect of compost:}

Regardeless of seasons and cultivars, results in Table (6) indicated that the highest means of nodules number and dry weight, shoot dry weight and its nitrogen content as well as seed and straw yields were obtained in plants inoculateded with Bradyrhizobium and fertilizerd with $2000 \mathrm{~kg}$ compost/fed. There are insignificantly difference between the use of $2000 \mathrm{~kg}$ compost/fed and/or the use of $20 \mathrm{kgN} / \mathrm{fed}$.

Table (6) shows that the maximum number of nodules and their dry weight were obtained in plants inoculated with Bradyrhizobium combined with $2000 \mathrm{~kg}$ compost/fed followed by those inoculated with Rhizobium plus $20 \mathrm{~kg}$ nitrogen/fed and those inoculated with Bradyrhizobium plus $1500 \mathrm{~kg}$ compost/fed. This could be due to the effect of the applied compost levels on plant growth, which is resulting from the production of plant growth regulators, vitamins leading to enhancement the uptake of plant nutrients, suppression of pathogenic of deleterious organisms as reported by many worker (Chebotar et al., 2001; Zaied et al., 2003 and Kennedy et al., 2004). Irrespective of inoculation, the nodulation exhibited a significant increase due to the application of compost at different levels in comparison to the treatments received no compost. Data also revealed significant increases of nodules number and dry weight for seed inoculated with 
Bradyrhizobium compared to uninoculated ones. In fact, the addition of enriched organic fertilizer to soil led to raise its fertility and microbial activity, which reflected on enhancing the root proliferation and nodule formation. Such promotion nodulation pattern for many legumes is confirmed by many investigators (El-Sawi et al., 2001; Bai et al., 2002; Abdel-Wahab and Ahmed, 2003 and Abdel-Wahab and Said, 2004).

Concerning the dry weight of 60 day-old soybean plants, data in Table (6) clearly illustrated that the addition of organic fertilizer led to a higher increase in shoots dry weight and its nitrogen content to be similar or higher than values obtained by using the recommended treatment. As well as, plant height, branches and pods number/ plant, seed index (Table 7) seed and straw yield, its nitrogen percentage (Table 8). This positive effect was magnified when combined with Bradyrhizobium inoculation particularly at high level of compost (1500 and/ or $2000 \mathrm{~kg} / \mathrm{fed}$ ), which gave the highest values of these parameters. Using such treatments exhibited the increases in characters under study over the control (zero compost). There are no significant differences due to the use any of 2000 $\mathrm{kgN} / \mathrm{fed}, 1500 \mathrm{~kg} / \mathrm{fed}$ or fertilizer with starter dose of $20 \mathrm{~kg} \mathrm{~N} / \mathrm{fed}$, respectively.

Table (6): Statistical main effect of Bradyrhizobium inoculation combined with different levels of compost on nodulation and growth of soybean during the two seasons of 2005 and 2006

\begin{tabular}{|l|c|c|c|c|}
\hline \multirow{2}{*}{ Treatments } & \multicolumn{2}{|c|}{ Nodulation } & \multicolumn{2}{c|}{ Shoot } \\
\cline { 2 - 5 } & $\begin{array}{c}\text { Number } \\
\text { plant }\end{array}$ & $\begin{array}{c}\text { Dry weight } \\
\text { (mg/plant) }\end{array}$ & $\begin{array}{c}\text { Dry weight } \\
\text { (g/plant) }\end{array}$ & $\begin{array}{c}\text { N-content } \\
\text { (mg/plant) }\end{array}$ \\
\hline Inoc. + 0 Kg compost/fed & 8.0 & 83.9 & 27.0 & 541.2 \\
\hline Inoc. + 500 Kg compost/fed & 14.0 & 138.5 & 34.5 & 620.7 \\
\hline Inoc. + 1000 Kg compost/fed & 17.3 & 181.6 & 39.5 & 873.2 \\
\hline Inoc. + 1500 Kg compost/fed & 19.5 & 193.4 & 46.5 & 1129.6 \\
\hline Inoc. + 2000 Kg compost/fed & 21.3 & 228.6 & 51.2 & 1288.3 \\
\hline Inoc. + 20 Kg N/fed & 20.5 & 212.2 & 48.6 & 1160.56 \\
\hline Un-inoc. + 70KgN/fed & 0.0 & 0.0 & 52.3 & 1357.8 \\
\hline LSD 0.05 & 2.1 & 20.4 & 4.5 & 84.2 \\
\hline
\end{tabular}

Table (7): Statistical main effect of Bradyrhizobium inoculation combined with different levels of compost on yield component of soybean during the two seasons of 2005 and 2006

\begin{tabular}{|l|c|c|c|c|}
\hline Treatments & Plant height & $\begin{array}{c}\text { Branches } \\
\text { number } \\
\text { /plant }\end{array}$ & $\begin{array}{c}\text { Pods } \\
\text { number } \\
\text { /plant }\end{array}$ & $\begin{array}{c}\text { 100-Seed } \\
\text { weight } \\
\text { (g) }\end{array}$ \\
\hline Inoc. + 0 Kg compost/fed & 59.18 & 1.2 & 35.225 & 11.55 \\
\hline Inoc. + 500 Kg compost/fed & 68.40 & 1.6 & 41.25 & 12.95 \\
\hline Inoc. + $1000 \mathrm{Kg}$ compost/fed & 78.98 & 2.475 & 48.225 & 14.225 \\
\hline Inoc. + $1500 \mathrm{Kg}$ compost/fed & 91.6 & 2.9 & 58.925 & 17.775 \\
\hline Inoc. + $2000 \mathrm{Kg} \mathrm{compost/fed}$ & 96.63 & 3.175 & 60.3 & 18.625 \\
\hline Inoc. + 20 Kg N/fed & 91.23 & 2.8 & 54.525 & 16.825 \\
\hline Un-inoc. + 70KgN/fed & 966.25 & 3.25 & 60.425 & 19.2 \\
\hline LSD 0.05 & 5.3 & 0.4 & 4.8 & 3.2 \\
\hline
\end{tabular}

The increases in the previous parameters may be attributed in part to the effect of organic fertilizer used on the production of humus substances, which improves the physical and chemical properties of soil, increases the water holding capacity, availability of nutrients, which leads to establish suitable growth media for growing plants. Claims to the promotion effect of enriched bio-organic soil conditioner on plant growth were reported by various workers, Bashan and Levanony (1990), Antoun et al. (1998) and Abdel-Wahab and Ahmed (2003) who explained the favorable effects of the combination between compost and biofertilizers on the basis of the beneficial effects of bacteria on the nutrient 
availability, vital enzymes, hormonal stimulating effects on plant growth or the increasing of photosynthetic activity.

Table(8):Statistical main effect of Bradyrhizobium inoculation combined with different levels of compost on seed and straw yields of soybean during the two seasons of 2005 and 2006

\begin{tabular}{|l|c|c|c|c|}
\hline \multirow{2}{*}{ Treatments } & \multicolumn{2}{|c|}{ Yield (ton/fed) } & \multicolumn{2}{c|}{$\% \mathbf{N}$} \\
\cline { 2 - 5 } & Seed & Straw & Seed & Straw \\
\hline Inoc. $+0 \mathrm{Kg}$ compost/fed & 1.026 & 1.178 & 2.995 & 1.470 \\
\hline Inoc. $+500 \mathrm{Kg} \mathrm{compost/fed}$ & 1.292 & 1.494 & 3.190 & 1.573 \\
\hline Inoc. $+1000 \mathrm{Kg}$ compost/fed & 1.609 & 1.810 & 3.185 & 1.738 \\
\hline Inoc. $+1500 \mathrm{Kg}$ compost/fed & 2.045 & 2.443 & 3.263 & 2.123 \\
\hline Inoc. $+2000 \mathrm{Kg} \mathrm{compost/fed}$ & 2.271 & 2.620 & 3.450 & 2.263 \\
\hline Inoc. $+20 \mathrm{Kg} \mathrm{N} / \mathrm{fed}$ & 1.901 & 2.206 & 3.345 & 2.215 \\
\hline Un-inoc. $+70 \mathrm{KgN} / \mathrm{fed}$ & 2.333 & 2.751 & 3.578 & 2.350 \\
\hline LSD 0.05 & 0.280 & 2.310 & 0.520 & 0.492 \\
\hline
\end{tabular}

\section{3- Statistical main effect of cultivars}

Data in Table (9) showed that the application of different levels of compost combined with Bradyrhizobium inoculation showed significant differences between the soybean cultivars due to all studied characters in both seasons except for seed and straw N \%, nodules number. Giza111 cultivar exceeded Crawford cultivar in nodules number and plant dray weight, growth, plant height, branches and pods number, seed index, seed and straw yields.

Such differences between cultivars might be attributed to the growth habit of each cultivar, which is governed by genetically factors and/or environmental condition. These results are in agreement with those reported by Zhou et al. (1994), El-Karamity (1998) and Abd El-Hafez (1999).

\section{4- Statistical main effect of season:}

The analysis of variance for seasons, treatments and their interactions of all studied characters are given in Table (9). Data revealed that there are significant differences in plant height, dry weight of shoots and shoots $\mathrm{N}$-content as well as seed and straw yields.

Table (9): Response of soybean parameters due to Statistical main effect of two cultivars and two seasons over Bradyrhizobium inoculation combined with different levels of compost

\begin{tabular}{|l|ccc|cccc|}
\hline \multirow{2}{*}{ Growth parameters } & \multicolumn{3}{|c|}{ Cultivars } & \multicolumn{3}{c|}{ Seasons } \\
\cline { 2 - 7 } & Giza 111 & Crawford & LSD 0.05 & 2005 & 2006 & LSD 0.05 \\
\hline Nodules number per plant & 13.6 & 10.0 & 1.6 & 12.9 & 15.8 & 1.4 \\
\hline Nodules DW (mg/plant) & 156.5 & 87.7 & 17.5 & 143.0 & 153.6 & 14.8 \\
\hline Shoot DW (g/plant) & 37.5 & 32.9 & 2.4 & 41.7 & 43.7 & 1.8 \\
\hline Shoot N-content (mg/plant) & 937.0 & 703.3 & 145.2 & 1011.9 & 979.9 & 126.8 \\
\hline Plant height (cm) & 78.0 & 60.0 & 6.2 & 86.9 & 80.6 & 4.4 \\
\hline Number of branches per plant & 2.3 & 1.8 & 0.2 & 2.5 & 2.5 & 0.1 \\
\hline Number pods per plant & 49.2 & 35.3 & 4.2 & 49.3 & 53.2 & 3.4 \\
\hline 100-Seed weight (g) & 14.5 & 11.6 & 1.8 & 15.4 & 16.3 & 1.3 \\
\hline Seed yield ton/fed & 1.76 & 1.17 & 0.22 & 1.790 & 1.775 & 0.12 \\
\hline Straw yield ton/fed & 2.00 & 1.42 & 0.45 & 2.037 & 2.106 & 0.12 \\
\hline$\% N$ in seed & 2.80 & 2.26 & 0.36 & 3.265 & 3.307 & 0.23 \\
\hline$\% N$ in straw & 1.73 & 1.50 & 0.22 & 1.945 & 1.977 & 0.18 \\
\hline
\end{tabular}

The second season of 2006 recorded the highest values of nodule number (15.8), nodule dry weight (153.6), shoot dry weight (43.7g/plant) as well 
as, the highest values of straw yield 2.106 ton/fed in the second season. While, in the first season of 2005 the highest values of shoots $\mathrm{N}$-content $(1011.9 \mathrm{mg}$ $\mathrm{N} /$ plant), plant height $(86.9 \mathrm{~cm})$ and seed yield $(1.790$ ton/fed) were recorded. These results indicated that season effect is important in the study. The differences between seasons reflecting the differences in weather and the environmental conditions along both studied seasons, suggesting the possibility to rise yield level by choosing the proper time of agriculture and other agronomic practices.

\section{REFERENCES}

Abd El-Ghaffar, A.S. (1978). The significance of organic materials to Egyptian agriculture and maintenance of soil productivity. FAO/STDA workshop on organic materials and soil productivity in the Near East 9-18 Oct.,1978, Alex. Egypt.

Abd El-Hafez, G. A. (1999). Studied the effect of sowing date and plant population density on growth and yield of some soybean cultivars, Ph.d. Thesis, Fac. Agric., Minia Univ., Egypt.

Abdel-Malek, Y. ; M. Monib and M.N. Zayed (1961). Bacteriological and chemical studies in rice straw compost. J. Soil Sci., U.R.E., 1: 51-66.

Abdel-Wahab, A.F.M. and A.S. Ahmed (2003). Preparation of bio-organic materials or their utilization as soil amendment and growth media. Annals Agric. Sci., Ain Shams Univ., Cairo, 48: 561-572.

Abdel-Wahab, A.F.M. and M.S. Said (2004). Response of Faba bean to bio and organic fertilization under calcareous Soil Conditions Egypt. J. Appl. Sci; 19 (1) 305-320.

Abo El-Soud, A.A.; M.A. El-Deeb and Kh.M. El-Yamani (2004). Improving of faba bean production by application of organic compost and rhizobial inoculation under newly reclaimed soil. Egypt. J. Appl. Sci., 19: 333-344.

Antoun, H.; J. Chantal.; N. Goussard.; R. Chabot and R. lalande (1998). Potential of Rhizobium and Bradyrhizobium species as plant growth promoting rhizobacteria on non-legumes: Effect on radishes (Raphanus sativus L.) Plant and Soil. 204 : 57-67.

Bai, Y., Pan, B., Charles, T.C. and Smith, D. L. (2002). Co-inoculation dose and root zone temperature for plant promoting rhizobacteria on soybean [Glycine max (L.) Merr] grown in soil less media.Soil Biology and Biochemistry,34:1953-1957.

Bashan, $Y$ and $H$. Levanony (1990). Current status of Azospirillum inoculation technology : Azospirillum as a challenge for agriculture. Can. J. Microbiol. 36: 591-608.

Chebotar, V.K.; C.V. Asis Jr and S. Akao (2001). Production of growth-promoting substances and high colonization ability of rhizobacteria enhance the nitrogen fixation of soybean when co-inoculated with Bradyrhizobium japonicum. Biol. Fertil. Soils, 34: 427-432.

Eghball, B. (2002). Soil properties as influenced by phosphorus and nitrogen-based manure and compost applications. Agron. J. 94: 128-135.

El-Karamity, A.E. (1998). Performance of soybean cultivars at different soil moisture levels. Zagazig. Agric. Res., 25(2):195-210.

El-Sawi, M. M., A. F. Abdel-Wahab and A. A. Abo El-Soud (2001). Effect of commercial biofertilizer "Nemaless" on nodulation, growth and yield of faba bean. J. Agric. Sci. ansoura univ.., 26: 3201 -3o26.

Fontaine, S ;A. Mariotti and L.Abbadie(2003).he priming effect of organic matter:a question of microbial competition.Soil Biol.\&Biochem.,35: 837-843.

Gomez, K.A. and A.A. Gomez (1984). Statistical Procedures for Agricultural Research. $2^{\text {nd }}$ edition. John Willey and Sons, New York. 
Harry, E.S. and T.W. Kown (1987). Soybean utilization. Van. Nostrand Reinhold Company, New York, pp. 346.

Hoitink, H.; M. Boehm and Y. Hadar (1993). Mechanisms of suppression of soil borne plant pathogens in compost amendment substrats. pp. 601-621. In: H. Hoitink and $\mathrm{H}$. Keener (eds.) Science and Engineering of Composting Renaissauce Puplications, Worthington. $\mathrm{OH}$.

Kennedy, I.R.; A.T.M.A. Choudhury; Mihaly L. Kecskes(2004).Non-symbiotic bacterial diazatrophs in crop-farming system: can their potential for plant growth promotion be better exploited Soil Biol.And Biochem,36:1229-1244.

Martin, D.L. and G. Gershuny (1992). "The Rodale Book of Composting". Rodale Press, Emmaus, Pennsylvania.

Mekail, M.M. (1998). Evaluation of some natural organic wastes as amendments for virgin coarse textured soils. I. Effect of filtermud (Pressmud) and nitrogen application on some soil properties and wheat yield. J. Agric. Sci., Mansoura Univ., 23: 5749-5762.

Mekhemar, G.A.A.; M. Shaaban; A.A. Ragab and A.M.M. Biomy (2005). Response of fab bean to inoculation with Rhizobium leguminosarum bv. Viceae and plant growth promoting rhizobacteria under newly reclaimed soils. Egypt. J. Appl. Sci., 20: 126-144.

Negra, S. and N. Chirita (1994). Response of some new soybean cultivars and lines under conditions of the Agric., Res., Station at Secuiem Cecetari Agronomic in Moldova 27 (1-2): 121-126.

Noureldin, N.A. (1998). The History and Development of Soybean as a Crop in Egypt, Proceedings of the International Conference on Soybean Production under Newly Reclaimed Lands in Egypt, November, 28-29.

Page, A.I.; R.H. Miller and D.R. Keeney (1982). Methods of Analysis. Part 2, Chemical and Microbiological Properties, Second Edition, Amr. Soc. Agron. Inc., Amr. Soil Sci. Soc. pp. 595-624

Zaied, K.A.; A.H. Abd El-Hady; Aida H.Afify and M.A. Nassef (2003). Yield and nitrogen assimilation of winter wheat inoculated with new recombinant inoculants of rhizobacteria. Pakistan J. Biol. Sci., 6: 344-358.

Zhou, Z.Q.; N. Xu; Z.Y. Liu; L.J. Wang and Y.Q. Wang (1994). A study of agronomic characters and yield formation in summer sown soybean cultivars in Northeastern Hebei Soybean Sci.12:340-346.

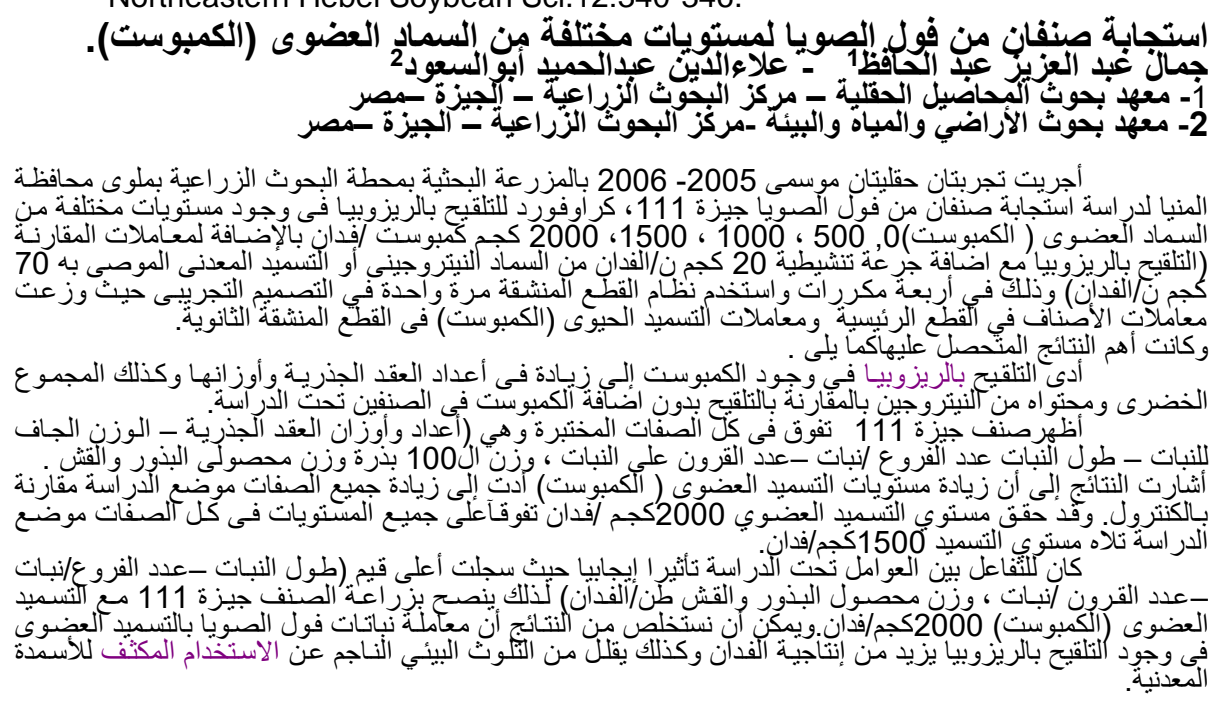

